\title{
The Swedish modal auxiliary ska/skall seen through its English translations
}

\author{
Karin Aijmer \\ University of Gothenburg (Sweden)
}

\begin{abstract}
The Swedish modal auxiliary ska/ll is interesting typologically because it is highly multifunctional with different functions in the systems of tense and modality. The aim of the paper is to investigate the translations of ska/ll into English as a methodology to throw light on its multifunctionality and the linguistic and extralinguistic factors determining its usage as a marker of obligation. The translations with must and the imperative point to the performative uses of $s k a / l l$ such as commands and orders. However, the translations also show that $s k a / l l$ is involved in offers, recommendations, suggestions, advice where the strength of imposition has been weakened. Other translations reveal more unexpected uses of ska/ll, for example to express negative evaluation if the context of the utterance could be interpreted as emotional or argumentative. The translations also draw attention to linguistic and non-linguistic factors aiding to distinguish functions of ska/ll (or choosing a particular translational correspondence).
\end{abstract}

Keywords: $s k a$, skall, obligation, multifunctionality, parallel corpus, English, Swedish

\section{Introduction}

Polysemy can be regarded as "an outstanding feature of modal verbs in the Germanic languages" (Narrog 2016: 98). The Swedish modal auxiliary ska/ll (English shall, German sollen, Dutch zullen) is, for example, interesting typologically because it is highly multifunctional with different functions in the systems of tense and modality. ${ }^{1}$ The Swedish reference grammar (Teleman et al. 1999: 312) describes ska/ll as having a temporal, deontic and epistemic meaning. The meanings are illustrated with their translations into English in examples (1)-(3).

(1) Det ska bli mitt livs verk. (GT1)

This will be my life's work.

(2) Du ska hem och äta! (ARP1)

You must go back and eat.

\footnotetext{
${ }^{1}$ The notation $s k a / l l$ is used to signal that the form ska includes the more formal and conservative skall.
} 
(3) Jo, men han lär ska ha en pojkbyting i alla fall. (AL1)

Well, but they do say he has a boy, all the same.

In example (1) the reading of $s k a$ (like English will) refers to the future. However, in (2) ska is translated with must and refers to an obligation imposed on the hearer most likely by the speaker. Ska/ll can also refer to what people say as evidence for what is claimed, as in (3) (a type of evidential modality), in which case it is more closely related to epistemic (modal) than deontic meaning.

Modal auxiliaries such as Swedish ska/ll and its correspondences in English have generally been analysed from a semantic point of view. In the literature on modality they are, for example, associated with such properties as necessity, moral desirability, subjectivity. According to Teleman et al. (1999: 316), ska/ll suggests that somebody demands a certain action by someone who is not expected to carry out the action on his or her own initiative (see example 2). The demand can be anchored in a social or functional norm. On the other hand, the categories needed to analyse the functions of modal auxiliaries may be different from those focusing on their semantic properties. In discourse ska/ll has for example functions to perform specific speech acts as well as other, less obvious uses.

The present study sets out to investigate the translations of ska/ll into English as a methodology to throw light on its multifunctionality and the linguistic and extralinguistic factors determining its usage. The paper takes the viewpoint that the different meanings of ska/ll and their frequencies can be described in terms of the well-known phenomenon of grammaticalization described for example by Hopper and Traugott (1993: xv): "the process whereby lexical items and constructions come in certain linguistic contexts to serve grammatical functions, and, once grammaticalized, continue to develop new grammatical functions" (quoted from Leech 2004: 75). The grammaticalization of ska/ll involves the use both as a modal auxiliary and as a future marker. However the present study is modest in its scope since the focus is on ska/ll as a modal marker. The study includes the present forms ska/ll ${ }^{2}$ and not the preterite form skulle (should) since skulle can be assumed to have a different interactional profile. The research questions are:

- What are the functions of ska/ll revealed by the translations into English and what do the translations tell us about the polysemy and multifunctionality of ska/ll?

- What are the linguistic and extra-linguistic factors or parameters determining how ska/ll has been translated (and indirectly what uses it has)?

- How can we explain the translation paradigms in terms of grammaticalization and ongoing semantic changes?

The paper is organised as follows. Section 2 gives an overview of research on factors playing a role for the uses of modal markers of obligation. The methodology and data are discussed in Section 3, and Section 4 presents the translations of ska/ll into English. Section 5 suggests a categorization of ska/ll based on the translation data. Section 6 is the conclusion.

\footnotetext{
${ }^{2}$ However, Hilpert (2006) found that ska and skall differed substantially in their collocational patterns, which suggests that they are associated with different meanings.
} 


\section{A review of relevant research on modal markers of obligation}

\subsection{Swedish ska/ll}

Previous work may be an aid to suggest factors determining how ska/ll has been translated. According to Teleman et al. (1994: 316), skall is used in sentences where someone or something demands a certain action from someone (or some body or institution). The requirement can be anchored in a functional or social norm (such as duty, custom, what is appropriate). It is also pointed out that skall often refers more directly to power. However, Teleman et al. do not discuss how the source of imposition (or other factors) can distinguish between the different modal meanings.

Hilpert $(2006,2008)$ has studied the grammaticalization of ska and skall with future meaning in a synchronic perspective. In a corpus study he examined what verbs were 'significantly attracted' to ska or skall in future and obligation meanings. The investigation showed that out of the three verbs which were most distinctive for ska (bli 'become', ske 'happen' and göra 'do') bli and ske strongly preferred inanimate subjects thus ruling out other meanings such as obligation (or intention). However, other verbs are strongly linked to $s k a$ with obligation meaning. Hilpert provides the following example with betala 'pay' where $s k a=$ 'must':

På något sätt ska de betala för vad de har gjort on some way must they pay for what they have done

'In some way they will have to pay for what they have done' (Hilpert 2006: 158)

Hilpert's study is interesting for the present study because it suggests that the meaning of the infinitival verb is important for how ska/ll is translated. Another result is that the item which should be the basis for the semantic description may be $s k a / l l$ followed by the infinitival verb and not the independent item ska/ll.

\subsection{English should, must, have to}

There is a rich literature on the linguistic and extra-linguistic factors playing a role for describing the uses of the modal markers of obligation in English. The most frequent obligation markers are should, must, have to. They have a large number of different meanings, which makes it difficult to categorize them. A basic factor is whether the modal markers of obligation are used performatively to indicate speech acts. This function is particularly associated with must, which is used for orders and commands, although, as pointed out by Narrog (2016: 111), basically all modal markers can have a performative function under the right conditions.

The study of obligation markers in English has also been influenced by recent research on the semantic changes they have undergone. On the basis of matching corpora from the 1960 s and the 1990s it has been reported that must, which has associations with direct speaker authority or power, is being replaced by have to where the source of imposition is external or objective (Smith 2003: 242; Leech 2004). The avoidance of an overt expression of power can also be a factor which can be studied in the ways ska/ll has been translated.

Many linguists have drawn attention to the factors strength and the source of imposition. However, when Myhill and Smith (1995) studied the discourse functions of obligation markers in different languages they found it difficult to apply these criteria to their data. A more useful criterion was based on the observation that obligation markers often expressed (negative) evaluation or affectedness usually on the part of the hearer. They 
describe the following example of have to as an interesting non-obligation use of have to illustrating the function of negative evaluation:

Why did he have to go out? Why didn't someone hearer him... Why did he have to hear noises in the night? (Myhill and Smith 1995: 248; simplified example).

Should as a modal auxiliary of obligation has been discussed less than must and have to. Verhulst and Heyvaert (2015) have described the difference between should and ought to in American English. They draw attention to the use of should to express the speaker's personal opinion in contexts of disagreement. For instance, in the example below, the speaker (a mother) is criticizing her daughter for going out without permission:

You shouldn't go out without telling us, Marilyn (Verhulst and Heyvaert 2015: 573).

\section{Methodology}

Translations are suitable for a usage-based or functional approach to language since they show what translators choose as the equivalent on the basis of a general idea of what is meant by the source item, the larger discourse context, knowledge of genre conventions, etc. The methodological assumption behind this type of study is that translations into a different language provide a window into its multifunctionality (see Ivir 1981, 1987 and the discussion by Altenberg and Granger (2002)). This idea has been further developed by Dyvik (1998, 2004) who argues that the ambiguity or vagueness of multifunctional items are reflected in their translations into another language and that it is possible to establish a function or subfunction on the basis of how the item is interpreted by the translator. In this perspective, a 'translational paradigm' showing how translators have interpreted ska/ll can be argued to give a more objective picture of its multifunctionality. Dyvik demonstrated how sense distinctions can be made by establishing translation correspondences starting both from originals and translations. However ska/ll has no obvious correspondence in the target language which could be used as the starting-point for examining the translations in the reverse direction. The translation correspondences used for establishing sense distinctions therefore represent translations in one direction only.

Crucial for the contrastive analysis is the availability of parallel corpora. The translations of ska/ll are taken from the English-Swedish Parallel Corpus (ESPC) (Altenberg and Aijmer 2000, Altenberg et al. 2001). The ESPC is a bidirectional corpus (with translations from English into Swedish and vice versa) consisting of roughly 3 million words of both fiction and non-fiction texts. For the present study I used translations from Swedish into English and restricted myself to fiction (1.5 million words).

The procedure followed in this study has been to extract the sentences with ska/ll together with their translations into English. Depending on the translational counterparts of ska/ll we can categorize the meanings of ska/ll as belonging in the domains of future and obligation (and epistemic modality/evidentiality). The translations can, however, also be assumed to give rise to a more detailed description of what ska/ll is doing in the discourse in different domains. 


\section{The translations}

\subsection{Overview}

The translations provide a fine-grained analysis of the different meanings or functions of ska/ll. The translations in Table 1 have been grouped into three major categories reflecting their uses to refer to future time, to mark obligation and evidential meaning. The examples where the translation is idiosyncratic or too far removed from the original have not been classified ('other').

Table 1. The translations of $s k a / l l$ in different meanings in the ESPC.

\begin{tabular}{|c|c|c|c|c|}
\hline & Translation & ska & skall & Total \\
\hline \multirow[t]{12}{*}{ Future } & will & 129 & 39 & 168 \\
\hline & be going to & 55 & 16 & 71 \\
\hline & shall & 33 & 8 & 41 \\
\hline & present tense of the main verb ${ }^{3}$ & 9 & - & 9 \\
\hline & be+-ing & 8 & 1 & 9 \\
\hline & be about to & 6 & - & 6 \\
\hline & infinitive $^{4}$ & 26 & 12 & 38 \\
\hline & be set on & 1 & - & 1 \\
\hline & be due to & 1 & - & 1 \\
\hline & intend to & 1 & - & 1 \\
\hline & begin to & 1 & - & 1 \\
\hline & Sub-total & 270 & 76 & 346 \\
\hline \multirow{17}{*}{$\begin{array}{l}\text { Deontic/ } \\
\text { Obligation }\end{array}$} & should & 59 & 12 & 71 \\
\hline & must & 20 & 4 & 24 \\
\hline & have/has to & 20 & 2 & 22 \\
\hline & be to & 11 & 16 & 27 \\
\hline & be supposed to & 11 & 5 & 16 \\
\hline & imperative $^{5}$ & 11 & 3 & 14 \\
\hline & wouldn't you like, (do) you/they want & 7 & 3 & 10 \\
\hline & may, might & 6 & - & 6 \\
\hline & need & 1 & 1 & 2 \\
\hline & can & 11 & 6 & 17 \\
\hline & I want to/I should like & 4 & 6 & 10 \\
\hline & be meant to & 3 & - & 3 \\
\hline & (perhaps) would & 1 & 1 & 2 \\
\hline & have got to & 1 & - & 1 \\
\hline & be allowed to & 1 & - & 1 \\
\hline & indeed & 1 & - & 1 \\
\hline & Sub-total & 168 & 59 & 227 \\
\hline \multirow[t]{3}{*}{ Evidential } & be supposed to & 6 & - & 6 \\
\hline & they do say & 1 & - & 1 \\
\hline & Sub-total & 7 & - & 7 \\
\hline Other & & 48 & 16 & 64 \\
\hline
\end{tabular}

\footnotetext{
${ }^{3}$ For example: När ska vi segla? - When $\underline{\text { do }}$ we sail? When the verb is in the present tense it is strictly not a translation of ska but of the whole verb phrase where ska occurs.

${ }^{4}$ An example is: När vill du att jag ska komma? (lit. "When do you want that I shall come"), translated as When do you want me to come? (BL1). The infinitive does not translate ska but ska followed by the main verb.

${ }^{5}$ The imperative translates the whole verb phrase rather than ska alone.
} 


\subsection{Discussing the translations}

Ska/ll only rarely corresponds to its semantic and formal cognate shall in the English translation. Instead it has a wide range of translations rendering aspects of its meaning. The translations into English give a rough picture of the polysemy of ska/ll and the parameters motivating the different meanings. In other words, "the one-to-many relationships among formal correspondents in pairs of contrasted languages is merely a reflection of similarity relationships between meanings and linguistic units in single languages" (Ivir 1981: 56). We can distinguish between translations where ska/ll has deontic or obligation meaning and examples with future or epistemic reference. In the obligation meaning the most frequent translations were modal auxiliaries (should, must, can may, might, need, would) or semimodals: have to, have got to, be to, ${ }^{6}$ be supposed to, be meant to. ${ }^{7}$ The translators have also used the imperative to translate $s k a / l l$ or a construction with a lexical verb (want).

Deontic modality is closely related to future meaning and it is challenging to keep the meanings apart. This is illustrated by shall in the translation which has not lost its obligation meaning when it refers to the future. ${ }^{8}$ Ska/ll has been regarded as having future meaning when it was translated by shall, will, be going to, be+ing form (e.g., the sign is coming down), be about to, be due to, be set on, the use of the present tense of the main verb, intend to, begin to. The meanings include prediction (will), intention (I'm going to), ingressive aspect (begin to), scheduled future event (present tense), an event expected to take place (be due to). The frequency of will is very high followed by be going to (see Hilpert 2008: 50 on different future interpretations).

The translations provide interesting information both about the frequency of different future meanings and the factors which are relevant when we talk about events in the future. The future meaning of ska/ll dominates $(53.73 \%)$ as reflected by the high frequency of will with future meaning (see Table 2). The majority of other meanings fall into the area of deontic or obligation modality. On the other hand, the evidential meaning is infrequent. It is represented by they do say and it is supposed in the translations.

Table 2. The frequency of future meaning, obligation (deontic) meaning and evidential meaning.

\begin{tabular}{|l|r|}
\hline Future & $346(53.73 \%)$ \\
\hline Obligation & $227(35.23 \%)$ \\
\hline Epistemic/evidential & $7(1.19 \%)$ \\
\hline Other & $64(9.94 \%)$ \\
\hline Total & $644(100 \%)$ \\
\hline
\end{tabular}

\section{Categorizing the functions of ska/ll meaning obligation}

The obligation meaning has been rendered in different ways in the translations suggesting that ska/ll has more than one meaning. The most frequent translations were should, must, have to and be to (see Table 1).

\footnotetext{
${ }^{6}$ With some hesitation I regarded be to as mainly having obligation meanings. According to Collins, be to typically has both modal uses and uses which "are more temporal than modal" Collins (2009: 85).

${ }_{7}$ Must, have to and be supposed to also have modal meanings (inference). These are generally easy to distinguish from the deontic or obligation meaning.

${ }^{8}$ Thus, Collins (2009: 137) refers to different uses of the deontic shall.
} 


\subsection{Ska/ll translated as should}

Obligation ska/ll was generally translated as should rather than shall ${ }^{9}$ (in the meaning obligation). ${ }^{10}$ Should was more frequent as a translation than must or have to (which have a strong deontic meaning). Several functions can be distinguished.

\subsubsection{Should with the function to convey the speaker's personal opinion or wishes}

The source of the imposition is the speaker as suggested by combinations such as I guess I should, perhaps we should, you don't think we should to make a suggestion or give a piece of advice.

Should was found in a subordinate clause under I guess to express the speaker's personal opinion, as shown in (4). I guess has the function to weaken the obligation meaning. The speaker wants to avoid threatening the hearer's face by mitigating his/her opinion.

(4) - En sån hamnar aldrig på mitt huvud, sa Wallander. Man kanske ska vara glad över att man inte längre är ordningspolis. (HM1)

Lit. "One perhaps should be glad..."

"I guess I should be glad I 'm not a cop in uniform anymore."

Perhaps we should in (5) and (6) presents what is said as a tentative suggestion.

(5) Men vi ska kanske akta oss lite för att ge den här mannen ett råd. (SC1) Perhaps we should be rather careful about giving this man advice.

(6) - Kanske ska vi hoppa över bakgrunden till dopnamnet och bara tala om vad han heter-? (ARP1)

"Perhaps we should skip the background of his baptism and just say what his name is..."

In (7) perhaps translates eller ('or'). The function is to recommend an action or make a polite suggestion:

(7) Eller ska vi, som ännu inte gjort vårt, ta och lösa problemet åt honom? (SC1) Perhaps we who are not yet old age pensioners should solve it for him?

Speakers avoid a direct expression of obligation unless the context is argumentative. In (8) the translation contains a subordinate clause with should under the polite formula you don't think. The speaker is making a polite suggestion that it would be better for the hearer to wait until the rain stops.

\footnotetext{
${ }^{9}$ The translations with shall in my data are mainly found in questions. Such examples are treated as deontic by Collins (2009:137) For example: "Vill du jag ska ta henne nu?" (AL1) with the translation "Shall I take her now?" However, a larger number of translations with deontic shall would be found in non-fiction (especially legal texts).

${ }^{10}$ On the other hand, there was no example of ought to in the translations. However this may be expected against the background that ought to has declined generally in English (Leech 2004: 70) or that ska has a different meaning than ought to.
} 
(8) Det är värst vad det regnar, ni ska inte vänta tills...

- Det kommer att ge sig, sa Aron. (GT1)

Boy, is it raining! You do n't think you should wait until..."

"It 's going to stop," said Aron.

Should in the translation was also found in interrogative sentences where the question form and the negation are strategies mitigating the imposition on the hearer by giving the hearer the option not to follow the suggestion:

(9) - Ska vi inte ta ut några patrullbilar? undrade Martinson. (HM2)

"Should n't we take a few patrol cars?" wondered Martinson.

\subsubsection{Should in contexts of disagreement}

When should is used in the translation of ska/ll this raises the question whether the context is argumentative. Should has the interpersonal function to take up a challenging position to the hearer or what is said in contexts where no agreement is presupposed (Verhulst and Heyvaert 2015: 573). In (10) the context suggests that the hearer disagrees with the speaker's opinion.

(10) - Jag tänkte att du borde veta om det, sa han. Förstår du vad det är som håller på att hända med polisen?

- Nej, sa Wallander. Och det ska du uppfatta som ett både uppriktigt och uttömmande svar. (HM1)

"I thought you ought to know about it," he said.

"Do you have any idea what 's going to happen to the police force?" "No," said Wallander. "And you should take that as the complete truth."

The factor involved in the choice of should in the translation is the different opinions of people discussing what is going to happen to the police force.

In (11), should is motivated by the argumentative context and by the emphasis on what the speaker has always said.

(11) Barn ska vara barn, det har jag alltid sagt. Låt dom behålla oskuldens vita änglavingar så länge som möjligt. (ARP1)

"Children should be children, I 've always said. Let them keep their white angel wings of innocence as long as possible.

Should in the translation indicates that the norm is what the speaker thinks (rather than some general recommendation).

(12) Om det är en verkligt fin årgång är det ett helgerån att hälla upp sherryn på karaff — det är ju rena mordet på bouqeten. En gammal fin sherry ska serveras direkt ur buteljen. (ARP1)

"If it 's really a genuinely fine vintage, then it 's blasphemy to decant it into a decanter - that 's straight murder of the bouquet. A fine old sherry should be served straight out of the bottle." 
As in other examples where should has been chosen in the translation the context in (12) involves the existence of other opinions.

5.1.3 Should with the function of expressing a negative emotion

Should was found in rhetorical why-questions with the illocutionary function of complaint:

(13) Varför ska vi släpa på tunga trasmattor när det finns bra såna i plast. (SC1) Why should we drag heavy rag rugs around when you can get such good plastic ones?

Example (14) is similar although skall does not occur in a why-question. Instead, the sentence is a statement asserting (or at least implying) that it should not be so difficult.

(14) Att det skall vara så svårt. (SCO1)

That it should be so difficult.

In (15) the "foolishness that you should stay in America" conveys the speaker's negative attitude (disapproval, irritation):

(15) — Den där fånigheten att du skall vara kvar Amerika är ingenting att diskutera, sade Gunnar. (JMY1)

"This foolishness that you should stay here in America is not to be discussed," said Gunnar.

Summing up, the translations with should illustrate several ways in which ska/ll can be used and confirm earlier analyses discussing the functions of should.

- Should is subjective and performative. It is used in non-argumentative (neutral) contexts to express the speaker's personal opinion in a tentative way (I think I should) and to make a tentative (you don't think you should), or co-operative suggestion (perhaps we should).

- Should can be used in argumentative contexts where the speaker disagrees with attitudes actualized by the preceding context.

- $\quad$ It is used (particularly in why-questions) to express negative effects such as irritation or impatience that things are not different.

\subsection{Ska/ll translated as have to}

5.2.1 Have to in the translation expressing negative feelings

Ska/ll can also be translated by a modal auxiliary or semi-auxiliary expressing strong necessity such as must or have to. The general analysis of have to is that it has to be chosen when the deontic source is external to the speaker (Collins 2009: 60). However this analysis does not cover all the ways it is used in discourse. As shown by Myhill and Smith (1995: 111), have to (unlike must) is often used in emotional contexts where it indicates negative affectedness (involving the speaker or the hearer) or something which is bad for everyone (cf. 
also Lewis 2015). This is illustrated by example (16), where have to conveys the speaker's negative feelings (irritation, impatience, complaint) with a situation where he has to pretend to think the sun is shining (while he is being examined by the doctor):

(16) — Varför ska jag låtsas att det är solsken? frågade jag där jag låg avklädd på den vita båren. (MS1)

"Why do I have to think of the warm sun?" I asked as I lay undressed on the white examination couch.

The translation with have to conveys the speaker's negative feelings such as annoyance with an undesirable situation. The question is not about the reason for a certain state of affairs but a complaint ("I shouldn't be thinking of the warm sun"). According to Narrog (2016: 111), "such usage does not appear to be directly performative, but aids in forming a specific type of illocution (in this case a complaint), and indicates negative affectedness, in this case on the part of the speaker".

In (17) have to has been chosen in the translation to convey the speaker's negative feelings (annoyance, irritation) with an unwanted situation ('I shouldn't really have to tell you this'):

(17) Inga byxor, hur många gånger ska man behöva säga det? (PP1)

No swimming trunks, how many times do I have to tell you?

The Swedish original contains ska behöva (lit. 'shall need to'). However need to is not used in the translation since it would not have conveyed the speaker's negative emotions.

In (18) the unpleasantness of "experience anything like this" is obvious from the situation and the use of have to in the translation:

(18) Jag hoppas ingen av er nånsin ska behöva uppleva det. (HM1)

I hope none of you ever has to experience anything like this."

In (19) the translator has used can rather than have to without any apparent difference of meaning to translate the construction skall behöva (rather than just skall). The question is rhetorical and can implies that "it should not be possible for anyone to sink so low":

(19) Hur lågt skall man behöva sjunka! (MR1)

How low can you sink?

Examples (17)-(19) suggest that it is the construction ska behöva ('shall need to') which is translated into English have to (or can) and serves as the basis for the interpretation of the negative meanings complaint, annoyance, irritation, etc.

In (20), the negative evaluation is additionally expressed by the superordinate clause (it's only that it's silly):

(20) Det är bara det att det är konstigt att det ska vara mil till en skvätt mjölk. (SC1)

It 's only that it 's silly to have to go miles for a drop of milk. 
Have to in the translation indicates that the meaning is evaluative rather than obligation:

(21) Den svenska sommaren är för vacker och för kort för att sånt här ska behöva hända. (HM1)

The Swedish summertime is too beautiful and too short for something like this to have to happen.

In (22), the negative interpretation is conveyed by the context and by have to in the translation. What is negative in this context is 'today's traffic' and how it threatens survival.

(22) vi ungdomar, Sveriges framtid och ljusa hopp, ska ju överleva dagens trafik så vi kan växa upp och bidra till morgondagens. (PP1)

we young hopefuls, the guardians of Sweden's future, have to survive today's traffic in order to grow up and contribute to tomorrow's.

\subsubsection{Have to in the translation with performative meanings}

Have to, like should, can have several different meanings. In example (23) it could be argued that have to is used performatively (instead of must or an imperative) to make a command or a request:

(23) -Vad heter hunden? frågar jag.

-Först ska du svara på en fråga! (PCJ1)

-What is the dog's name? I ask.

-First you have to answer a question!

\subsubsection{Translations with have to indicating habitual meaning}

When the subject of have to is a third-person noun phrase, ska/ll is anchored to some kind of norm (according to a regulation or with reference to what is habitual). In example (24) the verb is passive: the agent is unexpressed and have to has habitual meaning (cf. Smith 2003: 259):

(24) Varje helg skall marsvinen på vinden vägas. (PCJ1)

The guinea pigs in the attic have to be weighed every weekend.

To sum up, have to (rather than must) is used in the translation where the speaker is negatively affected by the verbal action or evaluates it negatively as a complaint. Especially in questions, the translations convey that has to has the function to express annoyance, complaint and irritation. Finally, performative and habitual meanings were also attested.

\subsection{Translations with be supposed to, be meant to, that means}

In the examples in the corpus be supposed to implies a negative evaluation of the hearer or the situation.

(25) - Jag har inte talat med henne ännu.

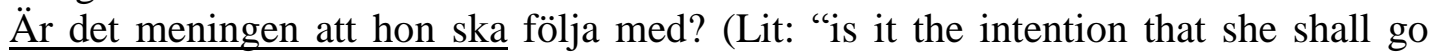
along") 
- Nej. (HM1)

I have n't talked to her about it yet."

"Is she supposed to go along?"

"No."

The translation by the passive be supposed to without an agent is more closely related to have to than to must since it is evaluative rather than performative. It refers to the previous scheduling of an event or to a previous agreement between the speaker and the hearer as the deontic source.

In (26) ska has been translated as was meant to. As with have to, the implication could be that the speaker is critical or reproachful (it shouldn't be simple):

(26) Vem har sagt att det ska vara enkelt. (PE1) Who said it was meant to be simple.

In (27) the translator has chosen a construction with do you want sb. to since the negative meaning (reproach) is already conveyed by the context:

(27) “Är det meningen att Borka ska ta över allt rövande också här i Mattisskogen”, undrade hon bistert, (AL1)

"Do you want Borka to take over all the robbing in Matt's Forest as well?" she asked sharply,

Summing up, the translations with be supposed to give additional evidence that ska/ll can express negative evaluation. The source of the imposition is what the speaker and hearer have agreed to do.

\subsection{Translations in the 'request domain'}

Modal markers of obligation can be assumed to have to do with action, and there is a close link between deontic modality and speech acts (Palmer 1986, Narrog 2016). In fact, many uses of ska/ll belong to the 'request domain' and have a performative or subjective quality. In the appropriate context (e.g. when it is translated by must or should) ska/ll can be interpreted as making a request, order, command or more positively as expressing advice, suggestion or recommendation.

5.4.1 Translations with must

Must is typically used in the translation in scenarios where the speaker has authority over the hearer and performs a command or an order.

(28) Du ska hem och äta! (ARP1)

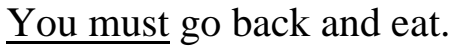

In (28), you must places the hearer under the obligation to act (you must go back and eat since I am telling you). Must go translates ska without a main verb but before an adverbial indicating direction (Teleman et al. 1999: 312). 
Translations with must can also reveal non-performative uses of ska/ll. In (29), where the deontic source is not specifically the speaker, must is not performative but the deontic source refers to social norms (religion, tradition, etc.):

(29) Man ska väva livet till slut, sade hon. (TL1)

"We must weave life to the end," she said.

\subsubsection{Translations with an imperative}

Among other translations of $s k a / l l$ in its performative use is the imperative. Imperatives can be regarded as illocutionary force indicators with a direct and performative function. Translations with an imperative come close to translations with must in assuming that the speaker has authority or power over the hearer. All the imperative examples translating skall express what Coates (1983: 32) refers to as "strong obligation" and paraphrases as "I order you to" (cf. Section 5.4.3 where ska/ll is translated as I want you to to convey a more polite meaning):

(30) Det ska du då inte bekymra dig om, sa hon. (KE2)

"Do n't you worry your heart about it," she replied.

(31) — Gå — naturligtvis ska du gå, säger han upprörd. (MS1)

"Run along then," he says outraged.

\subsubsection{Translations having a close association with politeness strategies}

A. Translations referring to the speaker's wishes:

I want you to can be used in social situations where the speaker has authority over the hearer and it is therefore sufficient to express what the speaker wants the hearer to do:

(32) Du ska säga efter mig på ungerska, säger han med sammanbitet allvar. (MS1) I want you to repeat something after me in Hungarian," he says with grim seriousness.

The translation with I should like us to, as in (33), indicates that the speaker is making a suggestion rather than an order:

(33) Jag vill att vi alltid ska kunna prata vid varandra. (TL1)

I should like us always to be able to talk to each other.

B. Translations directed to fulfilling the hearer's wishes:

In example (34) ska has been translated by a polite I want to. I want to aids in performing speech acts such as offers where the speaker promises to perform an action which is favourable to the hearer.

(34) — Men först ska jag spela någonting för dig, (MS1)

"But before we leave I want to play you something." 
C. Translations as questions about the hearer's wishes:

The translation with a question about the hearer's wishes in (35) indicates that the speaker is making an offer. More indirectness is not needed since the speaker is granting a favour (Leech 2014: 153).

(35) Ska du ha dej lite kaffe? (GT1)

You want a little coffee?

The translation would(n't) you like in (36) is a polite alternative to make an offer since it makes it easier for the hearer not to comply.

(36) Ska faster inte ha en liten sherry i alla fall? (ARP1)

"Would n't you like a little sherry after all, Auntie?"

The translations in (35) and (36) have in common that they draw attention to the interaction between ska/ll and polite strategies for performing speech acts such as asking about the hearer's wishes (an indirect way to make a polite offer).

In (37) the translation by do you want is associated with the function to make a suggestion:

(37) Ska vi dra det genast... (SW1)

Do you want to hear about it?

Lit. "ska' we go through it at once"

\section{Conclusion}

As a result of grammaticalization ska/ll has many different meanings. The translations showed that nearly half of the examples of ska/ll had a future meaning $(53.73 \%)$ while the deontic meaning represented roughly $35 \%$ of the examples. The evidential meaning was found only in a few examples. However, roughly $10 \%$ examples were difficult to classify.

The focus in this paper has been on what the translations can show about the functions of ska/ll and the factors governing the choice of translation (and distinguishing between different senses). The translations with must and the imperative point to the performative uses of ska/ll associated with imposed obligation and authority such as commands and orders. However, the translations also showed that ska/ll is involved in speech acts such as offers, recommendation, suggestion, advice where the strength of imposition has been weakened. The translation with I want you to or should like you to is another indication that the avoidance of strong imposition threatening the hearer's face is involved in how ska/ll is translated.

The translations also pointed to more unexpected uses of ska/ll. The translations with should, have to or be supposed to nearly always expressed negative evaluation if the context of the utterance could be interpreted as emotional or argumentative. Should and have to were found in usages where they were closely associated with illocution types such as reproach or complaint.

The translations also draw attention to linguistic and non-linguistic factors aiding to distinguish functions of $s k a / l l$ (or choosing a particular correspondence). Such factors are, for example, (a) the interplay with the meaning of the infinitival verb, (b) performativity (whether the speaker uses the obligation marker to perform a speech act or to report on 
habitual obligations), (c) the type of discourse context (whether there is a case of disagreement or high emotionality), and (d) the speakers' tendency to avoid explicitly expressing their authority or power. The translations could for example be explained by their interaction with politeness strategies.

\section{References}

Altenberg, B. and Aijmer, K. 2000. The English-Swedish Parallel Corpus: A resource for contrastive research and translation studies. In Corpus Linguistics and Linguistic Theory. Papers from the 20th International Conference on English Language Research on Computerized Corpora (ICAME 20) Freiburg im Breisgau 1999, C. Mair and M. Hundt (eds), 15-33. Amsterdam \& New York: Rodopi.

Altenberg, B. and Granger, S. 2002. Recent trends in cross-linguistic studies. In Lexis in contrast. Corpus-based approaches, B. Altenberg and S. Granger (eds), 3-48. Amsterdam/ Philadelphia: John Benjamins.

Altenberg, B., Aijmer, K. and Svensson, M. 2001. The English-Swedish Parallel Corpus (ESPC): Manual. Department of English, Lund University. Available at: http://www.sol.lu.se/engelska/corpus/corpus/espc.html.

Coates, J. 1983. The Semantics of the Modal Auxiliaries. London and Canberra: Croom Helm.

Collins, P. 2009. Modals and Quasi-modals in English. Amsterdam/New York: Rodopi.

Dyvik, H. 1998. A translational basis for semantics. In Corpora and Cross-linguistic Research: Theory, Method and Case Studies, S. Johansson and S. Oksefjell (eds), 51-86. Amsterdam/New York: Rodopi.

Dyvik, H. 2004. Translations as semantic mirrors: from parallel corpus to wordnet. In Advances in Corpus Linguistics. Papers from the $23^{\text {rd }}$ International Conference on English Language Research on Computerized Corpora, K. Aijmer and B. Altenberg (eds), 311-326. Amsterdam: Rodopi.

Hilpert, M. 2006. A synchronic perspective on the grammaticalization of Swedish future constructions. Nordic Journal of Linguistics 29(2): 151-172.

Hilpert, M. 2008. Germanic Future Constructions. A Usage-based Approach to Language Change. Amsterdam/Philadelphia: John Benjamins.

Hopper, P. and Traugott, E.C. 1993. Grammaticalization. Cambridge: Cambridge University Press.

Ivir, V. 1981. Formal correspondences vs translation equivalence revisited. Poetics Today 2(4): 5159.

Ivir, V. 1987. Functionalism in contrastive analysis and translation studies. In Functionalism in linguistics, R. Dirven and V. Fried (eds), 471-481. Amsterdam/Philadelphia: John Benjamins.

Leech, G. 2004. Recent grammatical change in English: data, description, theory. In Advances in Corpus Linguistics. Papers from the $23^{\text {rd }}$ International Conference on English Language Research on Computerized Corpora, K. Aijmer and B. Altenberg (eds), 61-81. Amsterdam/New York: Rodopi.

Leech, G. 2014. The Pragmatics of Politeness. Oxford: Oxford University Press.

Lewis, D. 2015. A comparable corpus approach to the expressions of obligation across English and French. Nordic Journal of English Studies 14(1): 152-173.

Myhill, J. and Smith, L. 1995. The discourse and interactive functions of obligation expressions. In Modality in Grammar and Discourse, J. Bybee and S. Fleischmann (eds), 239-292. Amsterdam: John Benjamins.

Narrog, H. 2016. The expression of non-epistemic modal categories. In The Oxford Handbook of Modality and Mood, J. Nuyts, J. and J. van der Auwera (eds), 89-116. Oxford: Oxford University Press.

Palmer, F. R. 1986. Mood and Modality. Cambridge: Cambridge University Press.

Smith, N. 2003. Changes in the modals and semi-modals of strong obligation and epistemic necessity in recent British English. In Modality in Contemporary English, R. Facchinetti, M. Krug and F. Palmer (eds), 241-266. Berlin/New York: Mouton de Gruyter. 
Teleman, U., Hellberg, S., and Andersson, E. 1999. Svenska Akademiens Grammatik. Stockholm: Norstedts.

Verhulst, A. and Heyvaert, L. 2015. Root modal uses of should, ought to and be supposed to in present-day British English: From patterns and profiles to proficiency guidelines. English Studies 96 (5): 562-595.

Author's address

Karin Aijmer

Department of Languages and Literatures

University of Gothenburg

PO box 200,

40530 Göteborg

Sweden

karin.aijmer@eng.gu.se 